\title{
Mucosal antibodies in inflammatory bowel disease are directed against intestinal bacteria
}

\author{
A Macpherson, U Y Khoo, I Forgacs, J Philpott-Howard, I Bjarnason
}

\begin{abstract}
In contrast with normal subjects where IgA is the main immunoglobulin in the intestine, patients with active inflammatory bowel disease (IBD) produce high concentrations of IgG from intestinal lymphocytes, but the antigens at which these antibodies are directed are unknown. To investigate the specificities of these antibodies mucosal immunoglobulins were isolated from washings taken at endoscopy from 21 control patients with irritable bowel syndrome, 10 control patients with intestinal inflammation due to infection or ischaemia, and 51 patients with IBD: 24 Crohn's disease (CD, 15 active, nine quiescent), 27 ulcerative colitis (UC, 20 active, seven inactive). Total mucosal IgG was much higher $(\mathbf{p}<\mathbf{0 . 0 0 1 )}$ in active UC (median 512 $\mu \mathrm{g} / \mathrm{ml})$ and active CD $(256 \mu \mathrm{g} / \mathrm{ml})$ than in irritable bowel syndrome controls $(1.43 \mu \mathrm{g} / \mathrm{ml})$, but not significantly different from controls with non-IBD intestinal inflammation $(224 \mu \mathrm{g} / \mathrm{ml})$. Mucosal IgG bound to proteins of a range of non-pathogenic commensal faecal bacteria in active CD; this was higher than in UC $(p<0 \cdot 01)$; and both were significantly greater than controls with non-IBD intestinal inflammation (CD $p<0.001$, UC $p<0 \cdot 01$ ) or IBS $(\mathbf{p}<0.001 \mathrm{CD}$ and UC). This mucosal IgG binding was shown on western blots and by enzyme linked immunosorbent assay (ELISA) to be principally directed against the bacterial cytoplasmic rather than the membrane proteins. Total mucosal IgA concentrations did not differ between IBD and controls, but the IgA titres against faecal bacteria were lower in UC than controls $(\mathbf{p}<0.01)$. These experiments show that there is an exaggerated mucosal immune response particularly in active CD but also in UC directed against cytoplasmic proteins of bacteria within the intestinal lumen; this implies that in relapse of IBD there is a breakdown of tolerance to the normal commensal flora of the gut.

(Gut 1996; 38: 365-375)
\end{abstract}

Keywords: inflammatory bowel disease, mucosal antibodies, intestinal bacteria.

King's College School of Medicine, London

Correspondence to: Dr I Bjarnason, Department of Clinical Biochemistry, King's College School of Medicine, Bessemer Road London SE5 9PJ.

Accepted for publication 28 September 1995
The aetiologies of ulcerative colitis (UC) and Crohn's disease (CD) are unclear. There are a number of suggestions of possible environmental or genetical causes including persistent infections, vasculitis, and immunological abnormalities (including autoimmunity). It is thought that CD and UC have different aetiologies on the basis of differences in location, the macroscopic and microscopic appearance of the disorders, and differences in mucosal immune activation (resulting in different cytokine and immunoglobulin isotype profiles). Despite this the two disorders may have very similar presentations and precipitants of clinical relapse. ${ }^{12}$

We have previously shown that during relapse of $C D$ intestinal permeability is increased $^{3-5}$ allowing access of luminal constituents to the mucosa. The acute inflammatory response is, however, quantitatively an order of magnitude greater than in other conditions with similarly increased intestinal permeability. ${ }^{5}$ This is probably caused by increased intestinal immune responsiveness caused by the underlying disease. The importance of the interaction between luminal antigens and the mucosal immune system as the mechanism of relapse in inflammatory bowel disease (IBD) is suggested by the following findings.

(1) Known causes of relapse (intestinal infections, non-steroidal anti-inflammatory drugs, and stress) all increase permeability across the epithelial cell layer or have the potential to do so. ${ }^{56}$ Moreover, normal intestinal permeability in patients with $C D$ predicts a long remission, whereas increased permeability heralds relapse. ${ }^{4}$

(2) Active $C D$ can be treated by faecal stream diversion, ${ }^{8}$ and recurrence of distal disease is largely avoided if an ileostomy is performed at the time of right hemicolectomy. ${ }^{9}$

(3) In strains of mice that have been genetically engineered to 'knockout' the T lymphocyte receptor, ${ }^{10}$ or either of the cytokines interleukin (IL) $2^{11}$ or IL10, ${ }^{12}$ intestinal inflammation develops with some parallels to the clinical presentation and pathological findings in human IBD. Significantly, where these mice were bred in a germ free environment they did not get intestinal inflammation. This shows that in these animal models of IBD the primary genetical abnormalities (which may be quite different from those in human UC or CD) each cause an increased mucosal immune response to the commensal intestinal bacteria, leading to active disease. In some human patients with active IBD antibiotic treatment may be effective. ${ }^{13}$ Clinical studies of bowel decontamination regimens in humans as a method of reducing disease activity have been inconclusive, however, possibly owing to difficulties in actually achieving decontamination or due to the use of non-absorbed antibiotics, which are directly toxic to the intestinal mucosa. 
In this paper we have directly tested the hypothesis that there is an abnormally increased mucosal immune response against non-pathogenic commensal intestinal bacteria in active CD and UC. Previous studies of circulating antibodies in serum samples of IBD patients initially proposed that there were high titres against enterobacteria (cross reactive with colonic mucins, ${ }^{14}$ but serum titres were subsequently shown not to be significantly different from control patients. ${ }^{15-17}$ Similarly the proposal of enterobacterial antigen specific activation of peripheral blood lymphocytes ${ }^{18}$ was not confirmed. ${ }^{19}$ However circulating immunoglobulin specificities may be unrepresentative of locally produced mucosal immunoglobulins. IgA is the main immunoglobulin produced in the intestinal mucosa of normal subjects, but in patients with active UC or $\mathrm{CD}$ both immunohistochemistry and cultured mucosal lymphocytes show that IgG production is dramatically increased $\left(\operatorname{IgG}_{1}\right.$ and $\mathrm{IgG}_{3}$ in $\mathrm{UC}$; $\mathrm{IgG}_{1}, \mathrm{IgG}_{2}$, and $\mathrm{IgG}_{3}$ in $\mathrm{CD}^{20-26}$ ). The antigens against which these mucosal immunoglobulins are directed have received comparatively little attention, except that monoclonal antibodies generated from mesenteric lymph nodes of IBD patients showed a higher frequency of binding to commensal intestinal bacteria in CD than in UC although control data could not be obtained. ${ }^{27}$

We report the isolation of immunoglobulins directly from the intestinal mucosa of patients with IBD and control subjects with and without intestinal inflammation and characterisation of their antigen specificity against non-pathogenic commensal intestinal bacteria.

\section{Methods}

Patients

Patients were studied while undergoing colonoscopy or flexible sigmoidoscopy to investigate lower abdominal pain and changed bowel habit, or to define the extent or activity of known IBD. The diagnoses of UC $(n=27)$ and $\operatorname{CD}(n=24)$ were made on standard criteria, ${ }^{28} 29$ with serial biopsies providing histopathological confirmation of disease in each case and histological UC disease activity. ${ }^{30}$ Crohn's disease was defined as quiescent with a Harvey Bradshaw index of $0-1^{31}$ and normal serum $C$ reactive protein. ${ }^{32}$ There were two groups of control patients. The first was a group of 21 patients suspected of having a functional disorder; no biochemical, haematological or microbiological abnormalities were found, colonic and terminal ileal histology was normal, and a final diagnosis of irritable bowel syndrome was made in each case. The second control group was a series of 10 patients with intestinal inflammation; seven patients had infectious gastroenteritis, two patients had diverticulitis, and one had ischaemic colitis. The Table shows patient details including activity, duration, and extent of disease, and current treatment.

Patients were prepared for colonoscopy by two oral doses of sodium picosulphate $(10 \mathrm{mg})$ taken 48 and 24 hours before the procedure and were sedated immediately before starting the examination by intravenous administration of $10-15 \mathrm{mg}$ diazepam and $75 \mathrm{mg}$ pethidine. Patients for flexible sigmoidoscopy were unprepared apart from a phosphate enema 90 minutes beforehand, and they were not sedated. A sample of serum was taken from each patient at the time of colonoscopy.

Informed consent was obtained from all patients, and the study was approved by the King's Healthcare Trust Ethics Committee.

\section{Isolation of intestinal mucosal immunoglobulin}

The colonic mucosa was washed under direct vision with $100 \mathrm{ml} 0.9 \%$ (w/v) saline injected through the flush channel of an Olympus CF200HL videocolonoscope or flexible sigmoidoscope, with the patient positioned to ensure that the relevant colonic segment was in a dependent position. Great care was taken to aspirate any fluid encountered in the colon during insertion of the colonoscope, and washings were only taken during withdrawal of the instrument so virtually all the wash fluid was aspirated (median $88 \mathrm{ml}$, range $72-96 \mathrm{ml}$ ). The wash fluid was aspirated after two minutes through the suction channel, and immediately aliquoted into $10 \mathrm{ml} 1 \mathrm{mM}$-phenylmethylsulphonylfluoride and $0.2 \mathrm{ml} 500 \mathrm{mM}$ EDTA (pH 8.0) to inhibit proteolysis. Two biopsy specimens were subsequently taken from each

Patient details

\begin{tabular}{|c|c|c|c|c|c|}
\hline Group & $\begin{array}{l}\text { Age } \\
\text { Mean } \\
(S D)\end{array}$ & $\begin{array}{l}\text { Age } \\
\text { (range) }\end{array}$ & $\begin{array}{l}\text { Duration } \\
\text { of disease } \\
\text { (mean and } \\
\text { range) }\end{array}$ & $\begin{array}{l}\text { Treatment } \\
\text { (details: } \text { no of } \\
\text { patients) }\end{array}$ & $\begin{array}{l}\text { Disease } \\
\text { distribution }\end{array}$ \\
\hline $\begin{array}{l}\text { Control subjects (Irritable bowel } \\
\text { syndrome) } n=21 \text {; } 16 \text { colonoscopy, } \\
5 \text { flexible sigmoidoscopy) }\end{array}$ & $52(19)$ & $26-80$ & None & None & None \\
\hline $\begin{array}{l}\text { Control subjects with intestinal } \\
\text { inflammation all flexible } \\
\text { sigmoidoscopy }\end{array}$ & 34 (13) & $17-62$ & $\begin{array}{l}5 \text { days }-13 \\
\text { days }\end{array}$ & $\begin{array}{l}\text { None apart from } 1 \text { patient } \\
\text { receiving cefuroxime and } \\
\text { metronidazole IV }\end{array}$ & $\begin{array}{l}\text { Salmonella colitis (5) } \\
\text { Shigella (1) } \\
\text { Campylobacter (1) } \\
\text { Ischaemic colitis (1) } \\
\text { Diverticulitis (2) }\end{array}$ \\
\hline $\begin{array}{l}\text { Crohn's disease }(n=24 \text {, colonoscopy } \\
15 \text { active, } 9 \text { quiescent) }\end{array}$ & $36(15)$ & $21-67$ & $\begin{array}{l}4 \text { years } \\
(0-16 \text { years })\end{array}$ & $\begin{array}{l}\text { None (12) } \\
\text { Elemental diet (5) } \\
\text { Oral prednisolone } \\
15-30 \mathrm{mg} / \text { day }(7)\end{array}$ & $\begin{array}{l}\text { Ileocolonic (17) } \\
\text { Colonic (7) }\end{array}$ \\
\hline $\begin{array}{l}\text { Ulcerative colitis ( } n=27 ; \\
21 \text { colonoscopy } \\
6 \text { flexible sigmoidoscopy; } \\
20 \text { active } 7 \text { inactive) }\end{array}$ & 37 (15) & $17-80$ & $\begin{array}{l}7 \text { years } \\
(0-32 \text { years })\end{array}$ & $\begin{array}{l}\text { None (13) } \\
\text { Rectal prednisolone } \\
20 \mathrm{mg} / \text { day }(6) \\
\text { Mesalazine } 800 \mathrm{mg} / \text { day (14) } \\
\text { Prednisolone } 5-30 \mathrm{mg} / \text { day (8) }\end{array}$ & $\begin{array}{l}\text { Remission (7) } \\
\text { Left-sided (14) } \\
\text { Pancolitis (6) }\end{array}$ \\
\hline
\end{tabular}


washing site to assess independently histological involvement (CD) or disease activity (UC).

\section{Precipitation of mucosal immunoglobulin from endoscopic washings}

To precipitate immunoglobulins $25 \mathrm{ml}$ of $50 \%$ (w/v) polyethylene glycol (PEG) 4000 were added to $100 \mathrm{ml}$ of mucosal washings and centrifuged at $6000 \mathrm{~g}$ for 10 minutes at $4^{\circ} \mathrm{C}$. The pellet containing immunoglobulin was resuspended in $2 \mathrm{ml}$ of $15 \%(\mathrm{w} / \mathrm{v})$ polyethylene glycol 4000 , which was reprecipitated by centrifugation. The precipitate was dried, and resuspended in $1 \mathrm{ml} 10 \mathrm{mM}$-TRIS $\mathrm{Cl}$, $50 \mathrm{mM} \mathrm{NaCl} \mathrm{pH} \mathrm{7 \cdot 4}$. This was confirmed routinely to contain undegraded immunoglobulins by western blot analysis, which were quantified and used in experiments to determine antibacterial membrane titres.

\section{Preparation of bacterial proteins}

Bacterial isolates of non-pathogenic Escherichia coli (K12; human faeces; O Rough H48; from Professor P J F Henderson, University of Cambridge), Klebsiella aerogenes (KCH908; human faeces; type 11; King's College Hospital), Bacteroides fragilis (KCH727; human faeces; King's College Hospital), Enterobacter faecalis (KCH806; human faeces; King's College Hospital), Staphylococcus epidermidis (KCH1004; skin swab; King's College Hospital), Haemophilus influenzae (KCH633; blood culture; King's College Hospital), and Clostridium perfringens (KCH 1001; human faeces; type A; King's College Hospital) were grown in liquid culture using aerobic or anaerobic medium from a single colony picked from selective agar plates. Bacteria were disrupted by sonication at mid-log phase (Soniprep 150, four bursts $25 \mu \mathrm{m}$ peak to peak) in $50 \mathrm{ml}$ of $10 \mathrm{mM}$-TRIS Cl, $1 \mathrm{mM}$-EDTA, $50 \mathrm{mM} \mathrm{NaCl}$ $\mathrm{pH} \mathrm{7.4;} \mathrm{the} \mathrm{cytoplasmic} \mathrm{fraction} \mathrm{was} \mathrm{then}$ obtained as the supernatant after centrifugation $\left(47000 \mathrm{~g}, 20 \mathrm{~min}, 4^{\circ} \mathrm{C}\right)$, the pellet was then washed as previously described ${ }^{33}$ and recovered by recentifugation $(47000 \mathrm{~g}, 20$ min, $4^{\circ} \mathrm{C}$ ) to obtain the membrane fraction.

Kaback vesicles were prepared from $E$ coli as previously described. ${ }^{34}$

\section{ELISA quantification of mucosal immunoglobulins and antibacterial immunoglobulins}

To quantify mucosal immunoglobulins and antibacterial immunoglobulins microtitre plates (96 wells, Maxisorb, Nunc) were coated with $50 \mu \mathrm{l}$ of monoclonal antihuman IgG and IgA (Sigma) at a dilution of 1:10 000 and $1: 1000$ respectively in $15 \mathrm{mM}-\mathrm{Na}_{2} \mathrm{CO}_{3}$, $35 \mathrm{mM}-\mathrm{NaHCO}_{3}, 0.02 \%$-sodium azide, $\mathrm{pH}$ $9 \cdot 6$ ) or $50 \mu \mathrm{l}$ of a combined preparation of cytoplasmic and membrane proteins at a concentration of $10 \mu \mathrm{g} / \mathrm{ml}$ ( $5 \mu \mathrm{g} / \mathrm{ml}$ each) in the same carbonate/bicarbonate coating buffer by incubation at $4^{\circ} \mathrm{C}$ overnight. The plates were washed three times with phosphate buffered saline containing $0.05 \%(\mathrm{v} / \mathrm{v})$ TWEEN $20^{35}$ before blocking with $10 \%(\mathrm{w} / \mathrm{v})$ bovine serum albumin in phosphate buffered saline for two hours at $25^{\circ} \mathrm{C}$ and washed a further three times in phosphate buffered saline-TWEEN. Samples of mucosal immunoglobulins were serially diluted in phosphate buffered salineTWEEN, and $50 \mu \mathrm{l}$ of each was loaded in duplicate to the plates. A set of standards were made for every plate by serial dilutions of a immunoglobulin calibrant (Sheffield Protein Reference Unit) or a standard serum calibrant of known high time titre to each bacterial protein preparation. The standard serum calibrant for each bacterial preparation was obtained by screening serum samples from a set of entirely healthy volunteers; those chosen for their high titre were $E$ coli man aged $26 ; K$ aerogenes man aged 26; $B$ fragilis woman aged 28; Ent faecalis man aged $35 ; S$ epidermidis man aged 58; $H$ influenzae man aged $23 ; C$ perfringens woman aged 62; each serum was frozen in aliquots and thawed only once before use. After incubation for two hours at $25^{\circ} \mathrm{C}$ the plates were again washed in phosphate buffered saline-TWEEN, and $50 \mu \mathrm{l}$ of $1 \mu \mathrm{g} / \mathrm{ml}$ biotinylated antihuman IgG (Vector Laboratories, BA 3080) or biotinylated antihuman IgA (Vector Laboratories, BA 3030) was added to each well and incubated for a further two hours at $25^{\circ} \mathrm{C}$. The plates were again washed three times with phosphate buffered saline-TWEEN, and each well was incubated with avidin-horseradish peroxidase complex for 30 minutes at $25^{\circ} \mathrm{C}$ (Vectastain Elite ABC, Vector Laboratories). Unbound reagent was washed off with phosphate buffered saline-TWEEN, and the enzyme was detected by the addition of $50 \mu \mathrm{l}$ $4 \mathrm{mg} / \mathrm{ml} o$-phenylenediamine dihydrochloride in $50 \mathrm{mM}$ phosphate citrate buffer ( $\mathrm{pH} \mathrm{5.0)}$, $0.03 \%(\mathrm{w} / \mathrm{v})$ sodium perborate. This reaction was stopped after five minutes by the addition of $50 \mu 13 \mathrm{M}$ sulphuric acid, and the absorbance in each well was read at $495 \mathrm{~nm}$ using a Titertek Multiscan MCC/340 plate reader.

Each sample and standard was performed in triplicate, and mean results of IgG and $\operatorname{IgA}$ were expressed in $\mu \mathrm{g} / \mathrm{ml}$. Bacterial protein binding was based on a standard curve drawn for each plate using a serum calibrant (assigned as 100 ELISA units) known to bind well to each protein preparation. After subtraction of blanks (where no serum or mucosal immunoglobulin was added) each sample was read at the mid-linear portion of the curve, and mean results (of triplicates) were expressed in ELISA units/ $\mu$ g total IgG or IgA.

Binding of bacterial cytoplasmic or membrane proteins was measured as described above, except that the microtitre plates were coated with either cytoplasmic or membrane proteins at a concentration of $10 \mu \mathrm{g} / \mathrm{ml}$ in carbonate/bicarbonate buffer overnight. The sandwich assay for immunoglobulins was also adapted to measure IgG isotypes by coating the plates in carbonate/bicarbonate buffer overnight with specific IgG capture antibody (all mouse antihuman monoclonal antibodies were from Sigma (I-9388, I-9513, I-7260 and I-9888) and were used at the following 
concentrations: anti-IgG $1: 1: 3000 ;$ anti-IgG 1:2000; anti-IgG 3 , 1:5000; anti-IgG 4 , 1:2000).

Extensive preliminary experiments were performed to optimise these ELISA methods. Coating of the solid phase was most satisfactory in freshly prepared carbonate/bicarbonate buffer at $4^{\circ} \mathrm{C}$ overnight, and the concentration of each protein used to coat the plates was adjusted to obtain a steep reference curve (approximately $400 \mathrm{ng}$ of antihuman IgG, 350 ng of antihuman IgA, and $550 \mathrm{ng}$ of bacterial protein were bound during the coating procedure). A small amount of lipopolysaccharide (approximately $0.08 \mathrm{mEU}^{36}$ ) also bound to the wells with the bacterial membranes, but not the bacterial cytoplasmic protein preparations. In the case of bacterial proteins ${ }^{14} \mathrm{C}$-metabolically labelled proteins ${ }^{33}$ were used in control experiments to confirm that dissociation did not occur during the protocol. The incubation times after coating were set at two hours to

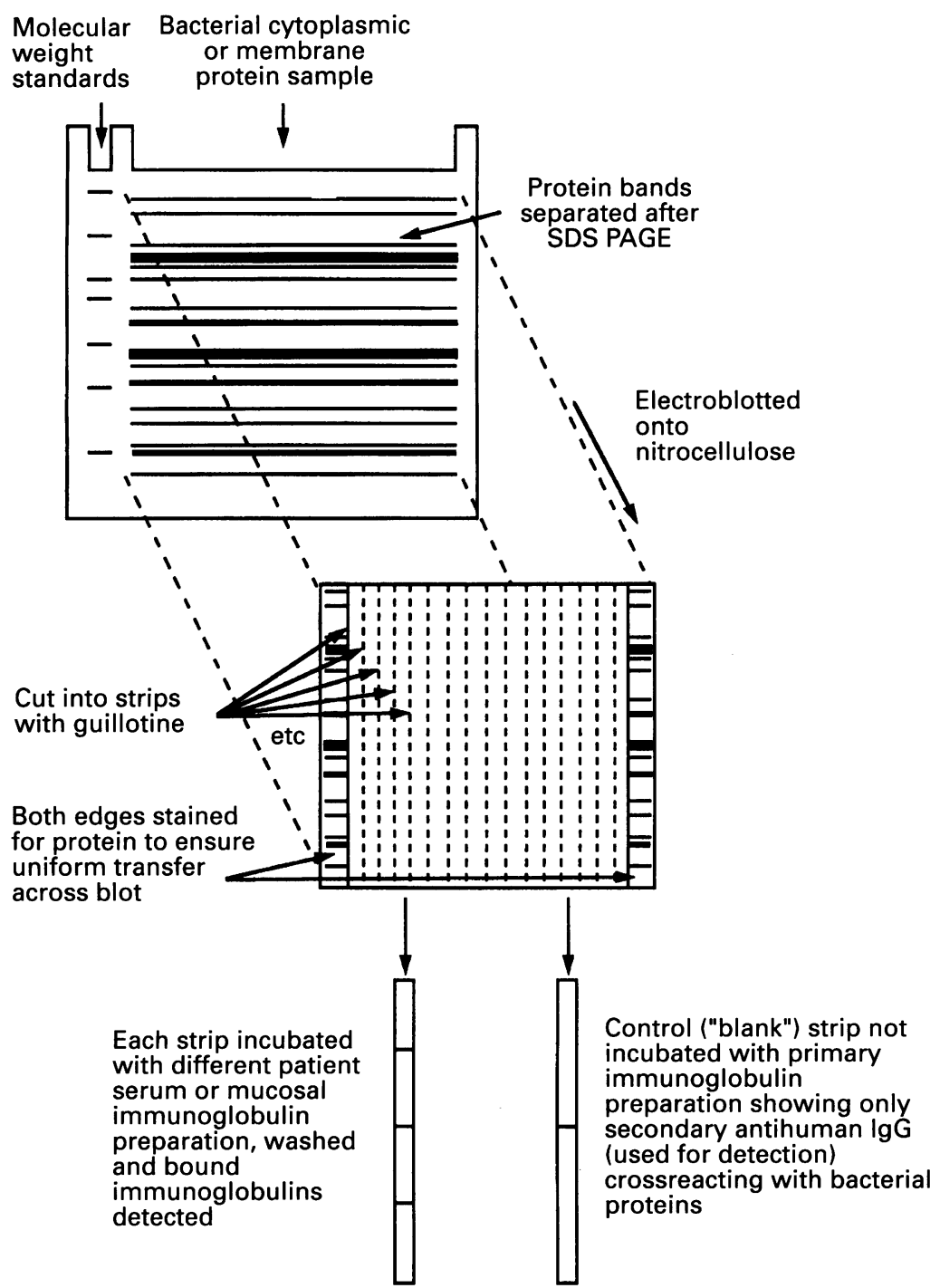

Figure 1: Method of assessment of mucosal and serum IgG binding to bacterial cytoplasmic or membrane proteins. Bacterial cytoplasmic or membrane proteins $(200 \mu \mathrm{g})$ were run in a single large well by $12 \cdot 5 \%$ SDS polyacrylamide gel electrophoresis. Molecular weight markers were run in a separate lane at the side of the gel and stained separately. The separated bacterial proteins were transferred to nitrocellulose, which was cut into strips, with each edge being stained for the bacterial protein bands with Amido black to ensure uniform transfer. Each intermediate strip was then incubated with either serum or mucosal immunoglobulin from an individual patient; after washing, specifically bound antibodies were detected using secondary biotin labelled antihuman IgG. Binding of secondary antibody independently of the mucosal or serum IgG was shown using 'blank' strips where no serum or mucosal immunoglobulin had been added. allow the binding reactions to reach equilibrium (after about 30 minutes), and the concentration of secondary antibody in the detection system was shown not to be limiting for each assay. We also confirmed that there was no significant cross reaction of the different antibodies used in the sandwich ELISAs.

\section{Protein assays}

Total proteins were assayed using the bicinchoninic acid (BCA) method (Pierce ${ }^{34}$ ). Albumin measurements were made by the Technicon $\mathrm{RA}$ radioimmunoassay method. To estimate the fraction of IgG derived from serum leakage, IgG and albumin were measured in both serum and unprocessed mucosal washing samples and the following equation was used:

$$
\frac{(\text { albumin }(\text { washings })) \div(\text { albumin } \text { (serum) })}{(\operatorname{IgG} \text { (washings })) \div(\operatorname{IgG} \text { (serum) })}
$$

\section{Western blots}

SDS poly- $(12 \cdot 5 \%)$ acrylamide gels were run as described previously ${ }^{32}$ using a mini-V.8.10 electrophoresis system (BRL). Molecular weight markers (rabbit muscle myosin, $205000 ; E$ coli $\beta$-galactosidase, 116000 ; rabbit muscle phosphorylase $B, 97400$; bovine serum albumin, 66000 ; ovalbumin, 45000 ; bovine erythrocyte carbonic anhydrase, 29 000; egg white lysozyme, 14300 ; Sigma) were run in a separate lane at the edge of the gel. Protein samples $(200 \mu \mathrm{g})$ from $E$ coli membrane or cytoplasmic proteins were prepared as described previously ${ }^{18}$ and were run in a single large well on each gel to achieve uniform separation of the proteins (Fig 1). After electrophoresis, the gels were either stained with Comassie Blue R, or transferred to Hybond $C$ (Amersham) using the electroblot stack assembly (150 V, 1 hour) with $25 \mathrm{mM}$-TRIS $\mathrm{HCl}, 192 \mathrm{mM}$-glycine, $10 \%(\mathrm{v} / \mathrm{v})$ methanol ( $\mathrm{pH} \mathrm{8.3)} \mathrm{transfer} \mathrm{buffer.}$ The blots were dried and a strip at each end was removed (Fig 1) and stained with Amido black to ensure clean separation of the mucosal proteins and uniform transfer. Markers were also visualised in a separate narrow well on the edge of the gel by Amido black staining. Between the end strips the blots of mucosal proteins were sectioned into $2 \mathrm{~mm}$ strips and processed further as described below.

Each strip of the mucosal protein blot was washed in phosphate buffered saline containing $0.05 \%$-TWEEN 20, and blocked by incubation in $10 \%$ bovine serum albumin at room temperature for one hour. They were then washed again in phosphate buffered salineTWEEN and incubated with different samples of serum $(500 \mu \mathrm{l})$ or mucosal immunoglobulin $(300 \mu \mathrm{l})$ preparations at a concentration of $150 \mu \mathrm{g} / \mathrm{ml}$ or $10 \mu \mathrm{g} / \mathrm{ml} \mathrm{IgG} \mathrm{respectively} \mathrm{in}$ separate test tubes for two hours. The strips were individually washed three times with $5 \mathrm{ml}$ of phosphate buffered saline-TWEEN in each tube and then incubated with biotinylated 
antihuman IgG (Vector Laboratories, BA3080) or antihuman IgA (Vector Laboratories, BA3030) at dilutions of $1: 1000$ and $1: 1500$ respectively. After washing three more times in $5 \mathrm{ml}$ phosphate buffered saline-TWEEN, bound immunoglobulin was detected on each strip by incubation with avidin-horseradish peroxidase complex for 30 minutes at $25^{\circ} \mathrm{C}$ (Vectastain Elite ABC, Vector Laboratories); unbound enzyme was washed off with phosphate buffered saline-TWEEN and the enzyme was detected using diaminobenzidine as a substrate.

\section{Statistical methods}

Statistical analysis was performed using the Wilcoxon signed rank test for unpaired samples using the SPSS package ${ }^{35}$ on the Digital Equipment Corporation VAX cluster (VAX 8800) of the computing service of the University of London.

\section{Results}

Immunoglobulins isolated from intestinal washings in control subjects and in IBD

Immunoglobulins isolated from colonoscopic washings by polyethylene glycol precipitation were quantified by sandwich ELIAs. Proteolytic degradation was routinely excluded by detecting intact $\alpha$ (IgA) or $\gamma$ (IgG) heavy chains of $M_{r} 55000$ and 50000 respectively in western blots (not shown). In control subjects with irritable bowel syndrome most of the immunoglobulin was IgA (median concentration $240 \mu \mathrm{g} / \mathrm{ml}$ ), with much lower amounts of IgG (median $1.43 \mu \mathrm{g} / \mathrm{ml}$; Fig 2). In patients with active $C D$ and UC total IgG was significantly increased compared with irritable bowel control subjects (medians $\mathrm{CD}=256 \mu \mathrm{g} / \mathrm{ml}$, $\mathrm{UC}=512 \mu \mathrm{g} / \mathrm{ml} ; \mathrm{p}<0.001$ for both). IgG

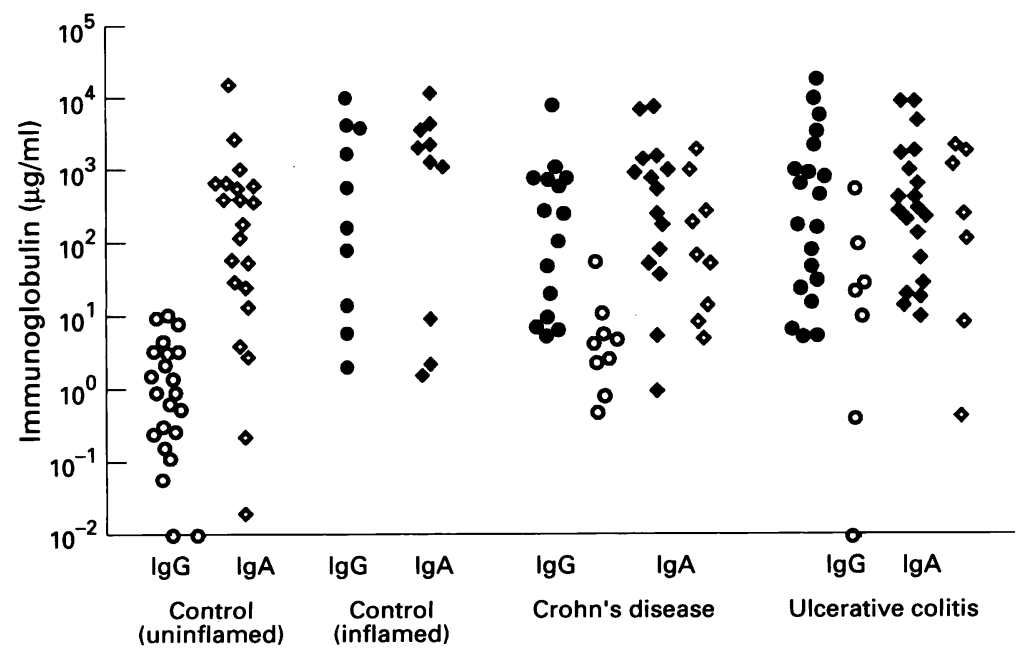

Figure 2: ELISA of IgG and IgA in samples obtained by colonoscopic washing from control and IBD patients. A sandwich assay method was used for each immunoglobulin with mouse monoclonal antihuman IgG and Ig $A$ capture antibodies respectively. The immunoglobulins were detected with biotinylated polyclonal mouse antihuman IgG or IgA by avidin conjugated horseradish peroxidase activity. Quantitative calibration curves were run on each plate using dilutions of serum standards of known immunoglobulin

concentration (Sheffield Protein Reference Unit, UK). Inflamed controls (gastrointestinal infection, diverticulitis or ischaemic colitis) and active CD disease or UC are shown by filled symbols. Irritable bowel syndrome controls or inactive IBD are shown by open symbols. concentration were similarly increased, however, in patients with intestinal inflammation due to gastrointestinal infections or ischaemia (median $224 \mu \mathrm{g} / \mathrm{ml}$ ), suggesting that the increase in IgG was not specific to IBD. Patients with inactive UC or in quiescent Crohn's had lower IgG concentrations compared with active disease in each case (medians UC $27 \mu \mathrm{g} / \mathrm{ml} \mathrm{p}<0.05$; CD $2 \mu \mathrm{g} / \mathrm{ml} \mathrm{p}<0.005)$. Concentrations of total IgA (Fig 2) or IgM (not shown) did not differ significantly between either control or IBD groups.

The IgG subtypes in washings from patients with IBD were predominantly $\operatorname{IgG}_{1}$ and $\mathrm{IgG}_{3}$ (medians $479 \mu \mathrm{g} / \mathrm{ml}$ and $51 \mu \mathrm{g} / \mathrm{ml}$ respectively) in active $\mathrm{UC}$ and $\mathrm{IgG}_{1}, \mathrm{IgG}_{2}$, and $\mathrm{IgG}_{3}$ (121 $\mu \mathrm{g} / \mathrm{ml}, 185 \mu \mathrm{g} / \mathrm{ml}$, and $36 \mu \mathrm{g} / \mathrm{ml}$ ) in CD.

\section{Albumin estimation of serum leakage}

To estimate the contribution of serum leakage to proteins isolated from the colonic mucosal washings, albumin was measured in the crude mucosal extracts (before polyethylene glycol precipitation) and compared with serum albumin in 16 control patients with irritable bowel syndrome, 11 patients with active $C D$, and 13 with active UC. Assuming that the same proportion of serum IgG leaks into the washings as serum albumin, the fraction of IgG in the washings derived from serum was then calculated from the ratios of albumin and IgG in washings and serum. The proportion of IgG derived from serum in $\mathrm{CD}$ patients was between $3 \cdot 2-18 \%$ (median $8 \cdot 6 \%$ ), UC $0 \cdot 13-16 \cdot 2 \%$ (median $7 \cdot 5 \%$ ), and controls $0 \cdot 01-8 \%$ (median $2 \%$ ). Thus most of the immunoglobulin in the washings was produced in the intestinal mucosa, and serum leakage contributed only a small fraction of the preparations.

\section{Mucosal antibody binding to intestinal and} non-intestinal bacteria proteins in IBD

Mucosal IgG was found to bind to proteins from non-pathogenic commensal strains of $E$ coli, $B$ fragilis, and $C$ perfringens in patients with active $C D$ and UC (Fig 3). In these experiments we corrected for different yields of mucosal immunoglobulins by expressing ELISA signals (binding) in relation to the total concentration of mucosal IgG or IgA. In each case, the titres for active $C D$ patients were significantly higher than those for active ulcerative colitis $(p<0 \cdot 01)$. The mucosal IgG titres from control patients with irritable bowel syndrome against these commensal bacteria were at the lower limit of detection of the assay system. Moreover IgG titres to the bacterial protein preparations from patients with nonIBD inflammation were also significantly lower than active CD $(p<0.001)$ or active UC $(p<0.01$; Fig 3$)$. Very similar results were obtained using proteins from non-pathogenic strains of $K$ aerogenes (non-IBD inflamed controls median 0.9 ELISA units/ $\mu$ g IgG, range $0 \cdot 17-17 \cdot 8, n=10$; active $C D$ median $259 \cdot 4$, range 68.3-398.6, $\mathrm{p}<0 \cdot 001, \mathrm{n}=13$; active UC median $7 \cdot 5$ range $0 \cdot 39-22 \cdot 7, \mathrm{p}<0 \cdot 05, \mathrm{n}=14$ ) 

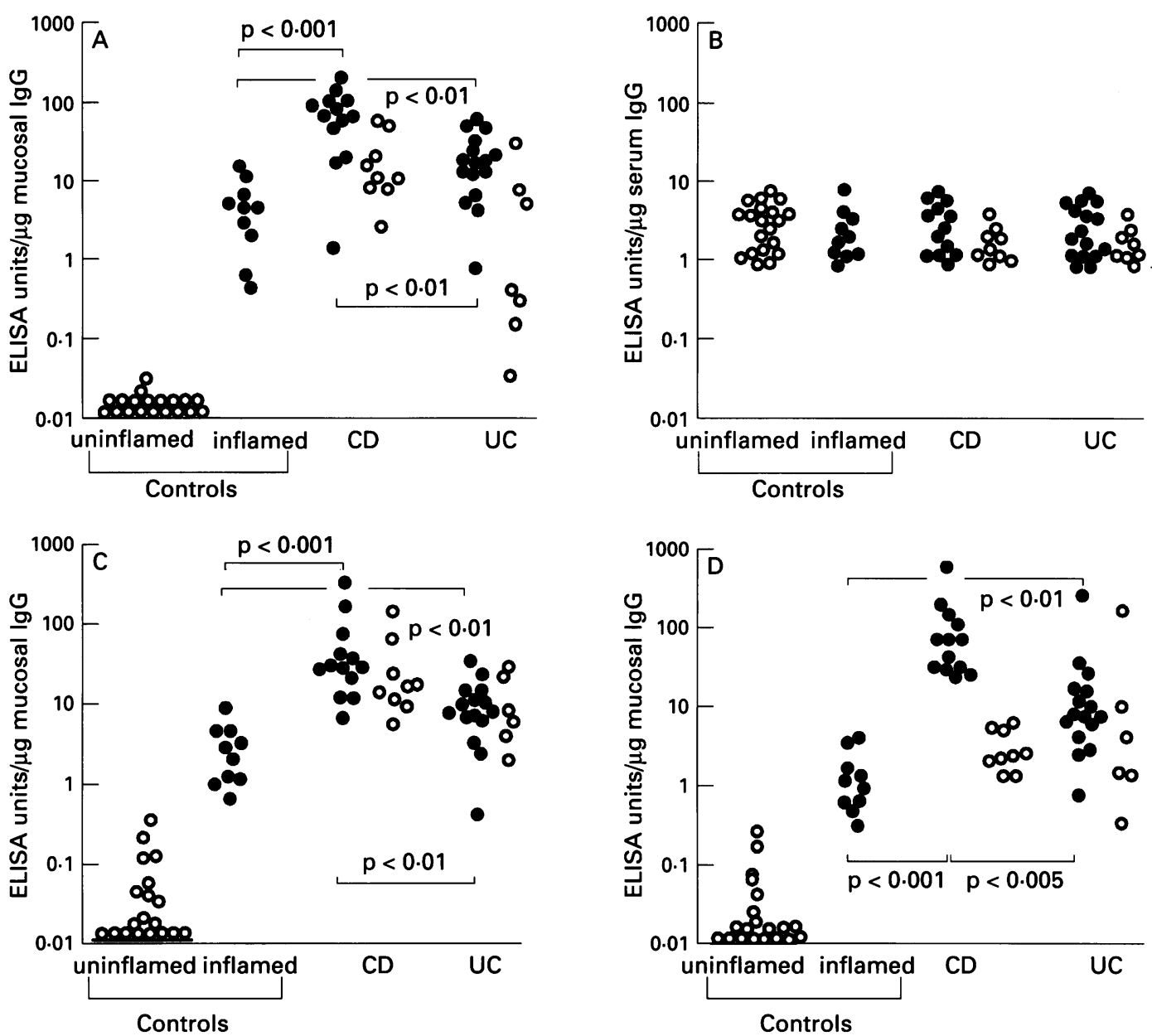

Figure 3: ELISA of binding by mucosal IgG from control and IBD patients against proteins of $(A)$ and (B) $\mathrm{E}$ coli (C) Bacteroides fragilis, and (D) $\mathrm{C}$ perfringens. Plates were coated with a preparation containing cytoplasmic and membrane proteins of each non-pathogenic bacterial isolate. Serial dilutions of samples of mucosal immunoglobulins from each patient were tested, and bound immunoglobulins were detected with biotinylated polyclonal mouse antihuman IgG by avidin conjugated horseradish peroxidase activity. Calibration curves were run for each plate using dilutions of a standard serum calibrant of known high titre to each bacterial preparation. IgG ELISA units were calculated from the linear mid-portion of the curve (after subtraction of the blank without added mucosal or serum immunoglobulin) using the standard calibrant for that bacterial species. Results were expressed in IgG ELISA units per $\mu g$ of total IgG. Inflamed controls (gastrointestinal infection, diverticulitis or ischaemic colitis) and active CD or UC are shown by filled circles. Irritable bowel syndrome controls or inactive IBD are shown by open circles.

and Ent faecalis (non-IBD inflamed controls median 0.42 ELISA units/ $\mu \mathrm{g}$ IgG, range $0 \cdot 11-3 \cdot 9, \mathrm{n}=10$; active $\mathrm{CD}$ median $146 \cdot 0$, range $12 \cdot 7-661 \cdot 7, \mathrm{p}<0 \cdot 001, \mathrm{n}=12$; active UC median 4.12 range $1 \cdot 19-52 \cdot 36, \mathrm{p}<0.01$, $n=12$ ). However, binding of intestinal bacterial proteins by mucosal immunoglobulins from patients with quiescent CD or inactive UC was not significantly greater than the non-IBD inflamed control group, except for quiescent $C D$, which showed significantly increased binding to $B$ fragilis $(p<0.05)$. In six of the patients with left sided UC washings were also taken from the macroscopically and histologically inactive area in the ascending colon; in each case the titres from the inactive area (for example, for $E$ coli median 0.7 ELISA units/ $\mu \mathrm{g}$ IgG; range 0.08-6) were lower than those from the active region (median 29.5, range $7-68$; $\mathrm{p}<0.001)$. There were no significant differences in serum titres to any of these bacterial preparations between controls, UC or CD groups (shown for $E$ coli, Fig 3B).

In contrast with the results with intestinal bacteria, measurements of mucosal immunoglobulin titres in IBD patients and controls using the non-intestinal bacteria
S epidermidis (Fig 4), $S$ aureus, and $H$ influenzae (not shown) showed very little measurable mucosal IgG directed against these organisms, whereas there were strong serum IgG titres. This shows that the mucosal immunoglobulin response against bacterial antigens is directed specifically against the colonic flora. Furthermore as the serum IgG titres against nonintestinal bacteria did not appear in the mucosa this also suggests that direct leakage from the serum does not contribute significantly to the IgG mucosal titres.

There were strong mucosal IgA titres in both groups of control patients against proteins from commensal intestinal bacteria (Fig 5). However IgA mucosal titres were significantly lower in patients with active UC compared with controls against $E$ coli $(\mathrm{p}<0.005)$, $B$ fragilis $(\mathrm{p}<0.005)$, and $C$ perfringens $(\mathrm{p}<0.01)$, although some control patients had IgA titres against commensal bacteria at or below the concentrations seen in UC. In no case were there significantly reduced mucosal IgA titres in active CD compared with the irritable bowel syndrome control group. Only very weak IgA titres were obtained to proteins from non-intestinal organisms $S$ epidermidis, $S$ aureus 


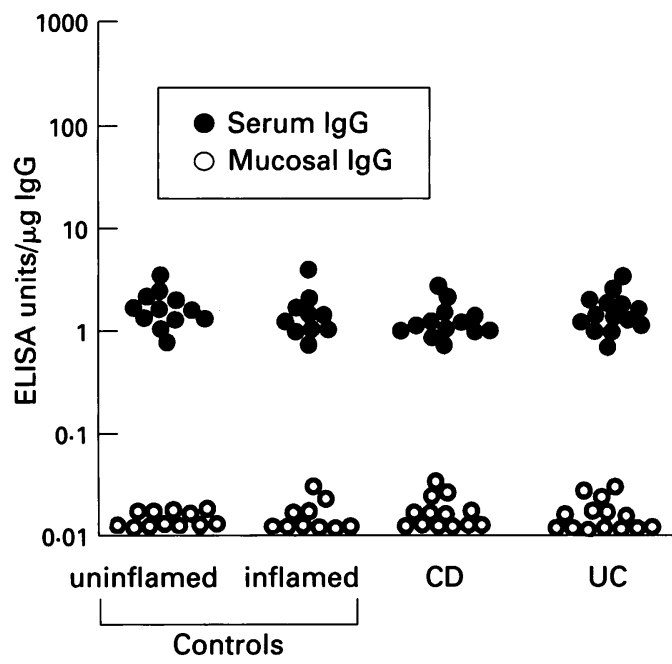

Figure 4: ELISA of immunoglobulin samples obtained by colonoscopic washing from control (irritable bowel syndrome $n=12$; inflamed controls $n=10$ ), and active IBD patients $(C D n=13 ; U C n=14)$ against membrane proteins of $\mathrm{S}$ epidermidis. Details were as described in the legend to Figure 3 except that plates were coated with a protein preparation of a non-pathogenic isolate of $\mathrm{S}$ epidermidis. Results were expressed in arbitrary IgG ELISA units calculated from the $\mathrm{S}$ epidermidis standard calibrant per $\mu g$ of total IgG.

or $H$ influenzae in any of the patient groups (not shown).
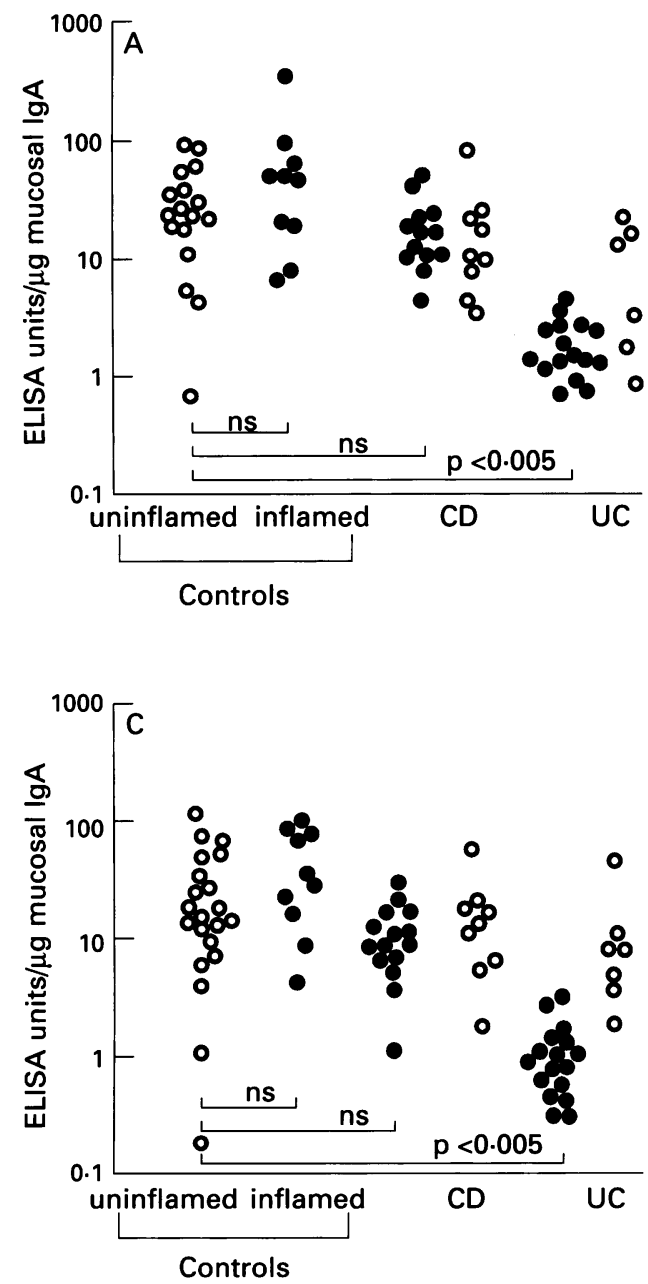

Mucosal antibody binding to cytoplasmic and membrane proteins of $\mathrm{E}$ coli

To investigate further the bacterial proteins bound by mucosal immunoglobulins in patients with IBD, we carried out the following experiments.

(1) ELISA assays were performed to assess mucosal immunoglobulin binding to the individual bacterial membrane or cytoplasmic protein fractions.

(2) Western blots were run in which cytoplasmic or membrane proteins were loaded en bloc from a single large well, and the nitrocellulose was cut into strips after electrophoretic transfer, thus there was an identical amount of each $E$ coli cytoplasmic or membrane protein band on every strip, which could be used to detect binding of immunoglobulins in individual mucosal or serum patient samples.

Both these techniques gave similar results. The ELISA assays showed that there was significantly greater binding of mucosal IgG in active $C D$ to the cytoplasmic proteins than to the membrane fraction $(p<0.001$; Fig $6 A)$, however low concentrations of serum immunoglobulin bound to both bacterial cytoplasmic and membrane protein fractions (Fig 6B). Mucosal IgA bound to both
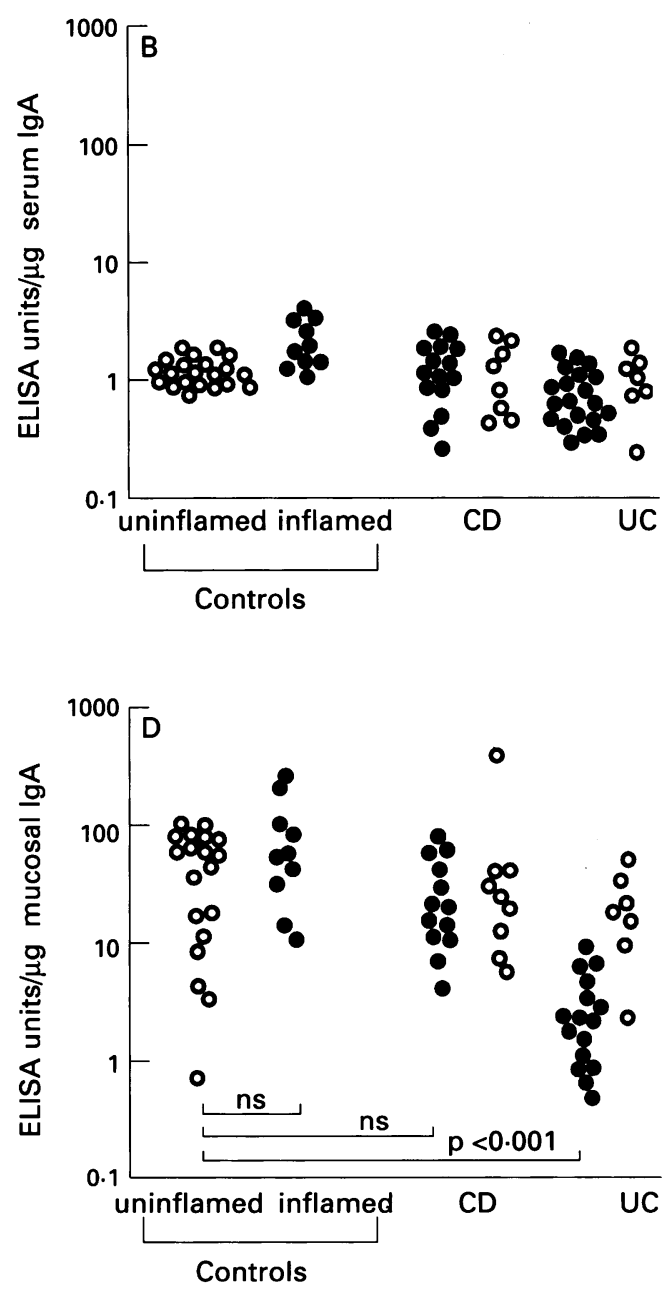

Figure 5: ELISA of binding by mucosal IgA from control and IBD patients against proteins of $(A)$ and $(B) \mathrm{E}$ coli, (C) $\mathrm{B}$ fragilis and (D) $\mathrm{C}$ perfringens. Details were as described in the legend to Figure 3 except that bound immunoglobulins were detected with biotinylated polyclonal mouse antihuman IgA by avidin conjugated horseradish peroxidase activity. Results were expressed in arbitrary $\operatorname{Ig} A$ ELISA units calculated from the standard calibrant for that bacterial species per $\mu \mathrm{g}$ of total IgA. Inflamed controls (gastrointestinal infection, diverticulitis or ischaemic colitis) and active $C D$ or UC are shown by filled circles. Irritable bowel syndrome controls or inactive IBD are shown by open circles. 
O Binding to cytoplasmic proteins $\square$ Binding to membrane proteins
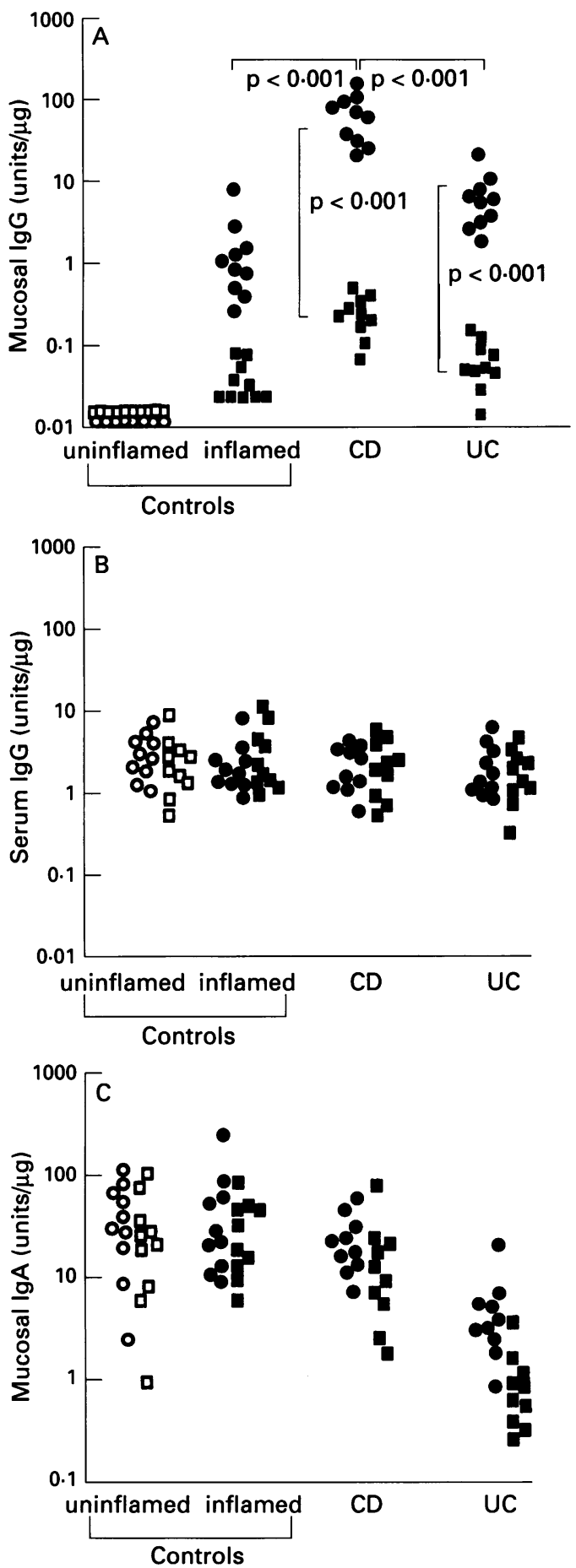

Figure 6: ELISA of immunoglobulin samples obtained by colonoscopic washing from control (irritable bowel syndrom $n=10$; inflamed controls $n=10)$ and IBD (CD $n=10$;

$U C n=10)$ against membrane or cytoplasmic proteins of $\mathrm{E}$ coli. Details were as described in the legend to Figure 2 except that plates were coated with either cytoplasmic (circles) or membrane protein (squares) preparations. Binding of $(A)$ mucosal IgG; $(B)$ serum IgG; and (C) mucosal IgA are shown. Results were expressed in arbitrary IgG or IgA ELISA units per $\mu g$ of total $\operatorname{Ig} G$ or IgA respectively. Irritable bowel syndrome controls are shown as open symbols, inflamed controls and active $C D$ or UC are shown by filled symbols.

membrane and cytoplasmic proteins in controls, yet membrane binding was significantly decreased $(p<0.01)$ in patients with UC
(Fig 6C). Very similar results were obtained for membrane and cytoplasmic proteins prepared from $B$ fragilis and $C$ perfringens as those shown in Fig 6 for $E$ coli.

On western blots mucosal IgG samples from patients with $C D$ clearly bound over 12 distinct cytoplasmic protein bands but very weak binding was seen in mucosal IgG samples of patients with UC and no bands were seen in inflamed controls (even though the same concentration of total mucosal IgG $(10 \mu \mathrm{g} / \mathrm{ml})$ was used in each case; Fig 7A). A single prominent band at $M_{\mathrm{r}} 59000$ on the $E$ coli cytoplasmic proteins in controls and UC patients was not due to binding of mucosal immunoglobulin, as it was also seen in blank strips to which no mucosal immunoglobulin had been added (Fig 7A), showing that the secondary antihuman IgG used to detect bound immunoglobulins crossreacts with this $E$ coli cytoplasmic protein. In contrast, mucosal IgG from active $C D, U C$ or control patients did not bind to membrane proteins either at a total mucosal IgG concentration of $10 \mu \mathrm{g} / \mathrm{ml}$ (Fig 7B) or at concentrations of up to $150 \mu \mathrm{g} / \mathrm{ml}$ even when the mucosal antibody preparations were precleared with lipopolysaccharide (not shown) despite the fact that satisfactory protein separation was shown by staining the end strips of the blot for protein (Fig 7B). Indeed, serum IgG from controls, $\mathrm{CD}$, and UC patients (incubated with the strips at the higher concentration of $150 \mu \mathrm{g} / \mathrm{ml}$ to visualise the bound immunoglobulin clearly as the signals were very weak at $10 \mu \mathrm{g} / \mathrm{ml}$ ) bound both $E$ coli membrane and cytoplasmic proteins from the same set of strips as in Fig 7A and 7B suggesting that the failure of mucosal IgG binding was due to the absence or blocking of specific immunoglobulins (Fig 7C). Similar results were also obtained on western blots of cytoplasmic and membrane proteins prepared from $B$ fragilis or $C$ perfringens and cytoplasmic and inner membrane proteins of Kaback vesicles from $E$ coli (not shown).

\section{Discussion}

In this paper we present and validate a new technique that permits the quantification and assessment of antigen specificity of undegraded mucosal immunoglobulins. In keeping with immunohistochemical studies we found greatly increased IgG concentrations from patients with IBD, which relates to disease activity. IgG recovery from patients with IBD after total intestinal lavage (with a nonabsorbable polyethylene glycol solution) also showed a correlation with disease activity. ${ }^{37}$ We have confirmed the different subclasses of IgG secreted in $C D\left(\operatorname{IgG}_{1}, \operatorname{IgG}_{2}\right.$, and $\left.\operatorname{IgG}_{3}\right)$ and UC (IgG ${ }_{1}$ and $\operatorname{IgG}_{3}{ }^{25}$ ). Most importantly we have shown that the intestinal IgG is specifically directed against cytoplasmic proteins from commensal bacteria in active $C D$ and UC, implying that these may be of major importance in the relapse of the two diseases.

There is increased binding of mucosal IgG in active $C D$ to proteins of both Gram positive and Gram negative non-pathogenic intestinal 

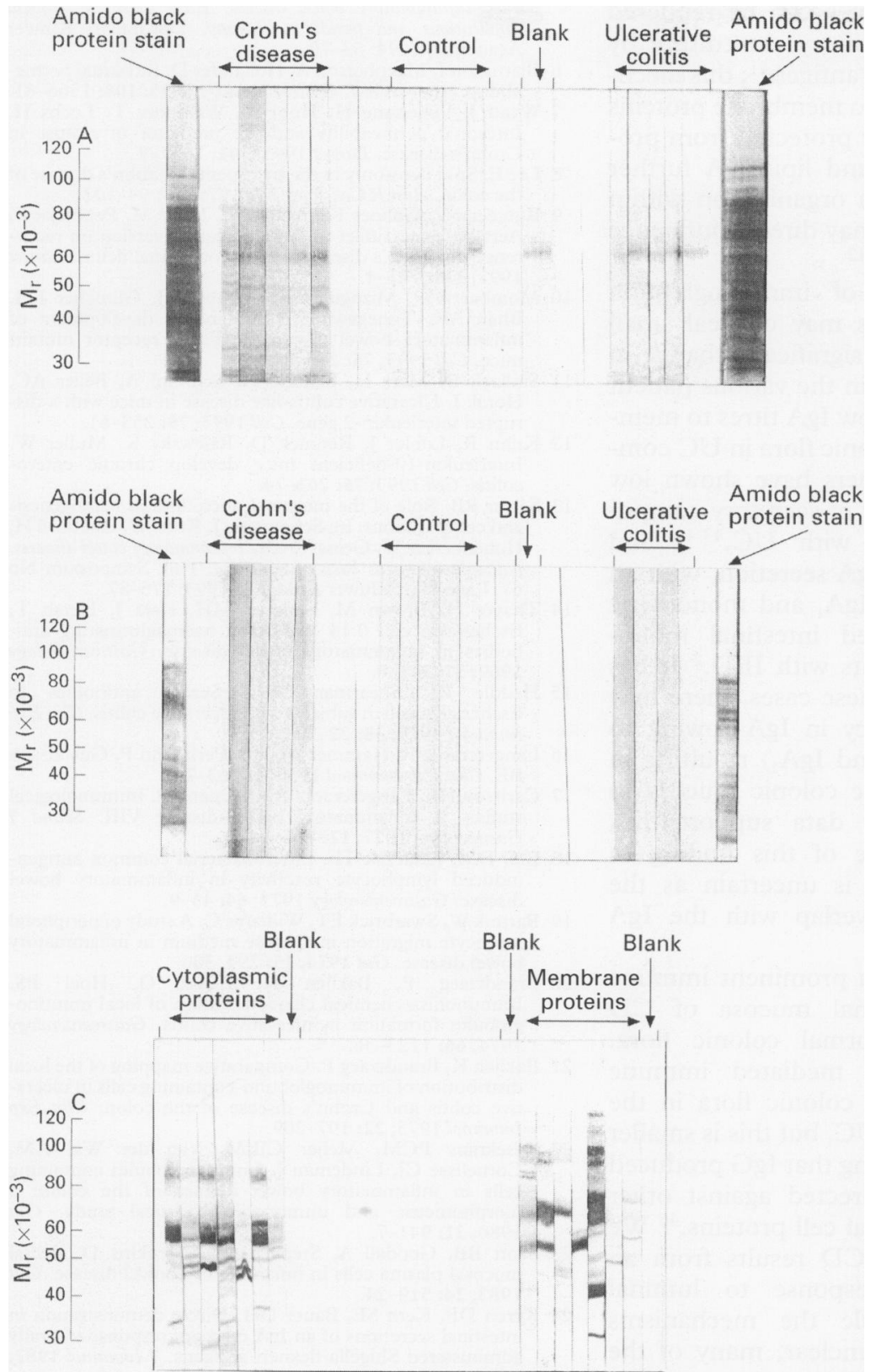

Figure 7: Binding of IgG from mucosal and serum immunoglobulins to E coli cytoplasmic or membrane proteins. $A$ western blot of $\mathrm{E}$ coli cytoplasmic or membrane proteins was processed as shown in Figure 1, with each strip representing binding of a different patient mucosal or serum immunoglobulin sample. Binding is shown $(A)$ by mucosal IgG $(10 \mu \mathrm{g} / \mathrm{ml})$ to $\mathrm{E}$ coli cytoplasmic proteins; (B) by mucosal $\mathrm{Ig} \mathrm{G}(10 \mathrm{\mu g} / \mathrm{ml})$ to $\mathrm{E}$ coli membrane proteins; and $(C)$ by control serum $\mathrm{IgG}(150 \mu \mathrm{g} / \mathrm{ml})$ to $\mathrm{E}$ coli cytoplasmic and membrane proteins to strips cut from the same blots shown for $(A)$ and $(B)$. UC and $C D$ serum samples gave similar results to those shown for $(C)$. The biotinylated (antihuman $I g G)$ secondary antibody also bound to a single $\mathrm{E}$ coli cytoplasmic protein of $M_{r} 59000$ (shown on the 'blank' strips where no mucosal immunoglobulin sample was added), showing that the band at Mrs9000 in control and UC samples in $(A)$ and $(C)$ is due to crossreaction of this detecting antibody and not to mucosal or serum IgG binding.

bacteria compared with active UC or inflamed (non-inflammatory bowel disease) controls. Mucosal IgG from active UC patients also shows increased binding compared with nonIBD inflamed controls although there is some overlap between the two ranges.

A significant advantage of the endoscopic mucosal wash technique over total intestinal lavage is that mucosal immunoglobulins can be obtained and isolated from defined regions of the intestinal tract. As the epithelial carrier for IgA (secretory component) does not translocate $\operatorname{IgG}$, however, the appearance of $\operatorname{IgG}$ in endoscopic mucosal washings, or in 'total intestinal lavage' fluid, ${ }^{37}$ may reflect either local mucosal production of immunoglobulin or serum leakage. Although this effect would reduce our IgG yields from controls with irritable bowel syndrome, the bacterial protein binding ELISA results are corrected for IgG (and IgA) yields in each sample. It nevertheless remains possible that some of the immunoglobulin that binds to enterobacterial proteins is derived from the serum by leakage rather than being produced locally within the mucosa, however the following three findings argue against this being a significant effect. Firstly, there is higher binding of Crohn's and UC mucosal IgG than serum immunoglobulin to commensal bacterial proteins when both are corrected for immunoglobulin concentration. Secondly, mucosal immunoglobulins did not show significant binding to non-intestinal commensal bacterial proteins, whereas there was strong binding by serum IgG. Thirdly, mucosal IgG bound to cytoplasmic but not membrane proteins of $E$ coli, and serum bound to both protein fractions. We have found that isolation of immunoglobulin from biopsy or surgical material results in most of the immunoglobulin being derived from serum owing to the vascularity of intestinal tissue suggesting that the mucosal washing or total intestinal lavage techniques are most suitable for obtaining large quantities of mucosal immunoglobulin for binding studies.

It has been well established that in CD there are activated $\mathrm{T}$ cells within the lamina propria. $^{38} 39$ The increased production of IgG specific for commensal bacterial cytoplasmic proteins in active $C D$ may reflect $T h_{1}$ help from these activated cells. ${ }^{40}$ Thus the recognition of bacterial peptides by this population of lymphocytes via their $T$ cell receptors would result in profound immune activation from any damage to epithelial integrity. This may also explain the increased response seen in active CD compared with active UC.

The mechanism that causes mucosal IgG production against bacterial cytoplasmic but not membrane proteins in active $C D$ and UC remains unclear. Serum immunoglobulins bind well both to membrane and cytoplasmic proteins, reflecting the systemic immune activation required to combat $E$ coli bacteraemias. It is possible that mucosal immunoglobulins do not bind membrane proteins because they also contain antibodies to other cell well components present in the membrane preparations (for example, lipopolysaccharide), which mask the protein binding, indeed some of the binding to the bacterial membrane fractions seen in ELISAs may reflect binding to lipopolysaccharide. Clearing with lipopolysaccharide or using inner membrane protein preparations, however, did not result in protein binding on the immunoblots. Alternatively, the response against membrane proteins may be inhibited. Knockout mice in which either the $T$ cell receptor or IL2 genes have been disabled get intestinal inflammation unless they are bred in a germ free environment. ${ }^{10-12}$ This has been interpreted as inactivating a $\mathrm{CD}^{+}{ }^{+} \mathrm{IL} 2 \cdot$ producing population of $\alpha \beta \mathrm{T}$ cells, which are capable of inhibiting the mucosal $B$ cell 
responses. As $\mathrm{T}$ cell clones can be rendered anergic (and hence inhibitory) in culture by repeated stimulation with antigen ${ }^{41}$; this mechanism may apply mainly to membrane proteins as they are comparatively protected from proteolytic digestion by bound lipids. A further possibility is that antigen organisation within the bacterial membrane may directly influence mucosal B cell tolerance. ${ }^{42}$

Although the range of immunoglobulin recovery in the washings may conceal small differences we found no significant change in total IgA concentrations in the various patient groups. We did observe low IgA titres to membrane preparations of colonic flora in UC compared with controls. Others have shown low concentrations of IgA, or of secretory component in some patients with $\mathrm{UC}, 4344$ and decreased spontaneous IgA secretion, with an increased proportion of $\operatorname{IgA} A_{1}$ and monomeric IgA secretion in isolated intestinal mononuclear cells from patients with IBD. ${ }^{2}$ It has been suggested that in these cases, there may be a functional deficiency in $\operatorname{IgA}$ (owing to decreased dimeric $\operatorname{IgA}$ and $\operatorname{Ig} \mathrm{A}_{2}$ ) resulting in increased exposure of the colonic mucosa to bacterial proteins. ${ }^{2}$ Our data support this, although the importance of this finding in relation to pathogenesis is uncertain as the lowest control values overlap with the IgA titres found in UC.

In summary, there is a prominent immune response in the intestinal mucosa of $\mathrm{CD}$ directed against the normal colonic flora. There is also an IgG mediated immune response against normal colonic flora in the mucosa of patients with UC, but this is smaller than that in $C D$, suggesting that IgG produced in the former is also directed against other antigens, such as epithelial cell proteins. ${ }^{45} \mathrm{We}$ suggest that relapse in CD results from an exaggerated immune response to luminal bacterial contents. While the mechanisms underlying this remain unclear, many of the known precipitants of relapse (for example, infections, non-steroidal anti-inflammatory drugs, and stress) have the potential to increase intestinal permeability, ${ }^{46-48}$ resulting in exposure of sensitised intestinal mucosa to luminal microbial antigens.

We are most grateful to Professor Alan McGregor for his support and encouragement during the course of this work. We would like to thank Drs A Marker and P O'Donnel for the histological assessments and Sister S Ridyard and the staff of the day surgery unit at King's College Hospital for assistance the day surgery unit at King's College Hospital for assistance during the collection of patient samples. We are also grateful to
Drs E Davis and H Jones for help with immunological techDrs E Davis and $\mathrm{H}$ Jones for help with immunological tech-
niques. Dr R Sherwood and $\mathrm{Mr}$ J Keating helped with the niques. Dr R Sherwood and Mr J Keating helped with the
microalbumin estimations. We are also grateful to Dr K Chester microalbumin estimations. We are also grateful to Dr K Chester
and Professor D Vergani for helpful discussion. This work was supported by an MRC Clinician Scientist Fellowship to AJSM.

1 Podolsky DK. Inflammatory bowel disease. $N$ Engl $f$ Med 1991; 325: 928-37, 1008-16.

2 Macdermott RP, Stenson WF. Alterations of the immune system in ulcerative colitis and Crohn's disease. Adv Immunol 1988; 42: 285-328.

3 Teahon K, Smethurst P, Levi AJ, Bjarnason I. The effect of elemental diet on intestinal permeability and inflammation in Crohn's disease. Gastroenterology 1991; 101: 84-9.

4 Teahon K, Smethurst P, Macpherson AJ, Levi AJ, Menzies IS, Bjarnason I. Intestinal permeability in Crohn's disease and its relation to disease activity and relapse following treatment with elemental diet. Eur $\mathcal{f}$ Gastroenterol and
Hepatol 1993; 5: 79-84.

5 Bjarnason I, Macpherson A, Menzies IS. Intestinal permeability: the basics. In: Sutherland LR, Collins SM, Martin
F, McLeod RS, Targan SR, Wallace JL, Williams CN, eds. Inflammatory bowel disease. Basic research, clinical implications and trends in therapy. Dordrecht: Kluwer Academic, 1994: 53-70.

6 Bjarnason I, Macpherson A, Hollander D. Intestinal permeability: an overview. Gastroenterology 1995; 108: 1566-81.

7 Wyatt J, Vogelsang H, Hubl W, Waldhoer T, Lochs H. Intestinal permeability and the predictor of relapse in Crohn's disease. Lancet 1993; 341: 1437-9.

8 Lee E. Split ileostomy in the treatment of Crohn's disease of the colon. Ann R Coll Surg Eng 1975; 56: 94-102.

9 Rutgeerts P, Goboes K, Peeters M, Hiele M, Pennickx F, Aerts $R$, et al. Effect of faecal stream diversion on recurrence of Crohn's disease in the neoterminal ileum. Lancet 1991; 338: 771-4.

10 Mombaerts P, Mizoguchi E, Grusby MJ, Glimcher LH, Bhan AK, Tonegawa S. Spontaneous development of inflammatory bowel disease in $\mathrm{T}$ cell receptor mutant mice. Cell 1993; 75: 275-82.

11 Sadlack B, Merz H, Schorle H, Schimpl A, Feller AC, Horak I. Ulcerative colitis-like disease in mice with a disrupted interleukin-2 gene. Cell 1993; 75: 253-61.

12 Kuhn R, Lohler J, Rennick D, Rajewsky K, Muller W. Interleukin-10-deficient mice develop chronic enterocolitis. Cell 1993; 75: 263-74.

13 Sartor RB. Role of the intestinal microflora in pathogenesis and complications. In: Scholmeric J, Kruis W, Goebbell H, Hohenberger W, Gross V, eds. Inflammatory bowel diseases: pathophysiology as basis of treatment. Falk Symposium No 67. Lancaster: Kluwer Academic 1993: 175-87.

14 Thayer H, Brown M, Sangree MH, Katz J, Hersh T. Escherichia coli $0: 14$ and colon haemaglutinating antibodies in inflammatory bowel disease. Gastroenterology 1969; 57: 311-8.

15 Heddle RJ, Shearman DJC. Serum antibodies to Escherichia coli in subjects with ulcerative colitis. Clin Exp Immunol 1979; 38: 22-30.

16 Langercrantz R, Hammerström S, Perlmann P, Gustafsson BE. Clin Exp Immunol 1966; 1: 263-76.

17 Carlsson HE, Langercrantz R, Perlmann P. Immunological studies in inflammatory bowel disease VIII. Scand $f$ Gastroenterol 1977; 12: 707-14.

18 Bull DM, Ignaczak TF. Enterobacterial common antigeninduced lymphocyte reactivity in inflammatory bowel disease. Gastroenterology 1973; 64: 43-9.

19 Bartnik W, Swarbrick ET, Williams C. A study of peripheral leucocyte migration in agarose medium in inflammatory bowel disease. Gut 1974; 15: 294-300.

20 Brandtzaeg P, Baklien K, Fausa O, Hoel PS. Immunohistochemical characterisation of local immunoImmunohistochemical characterisation of local immuno-
globulin formation in ulcerative colitis. Gastroenterology globulin formation

21 Baklien K, Brandtzaeg P. Comparative mapping of the local distribution of immunoglobulin-containing cells in ulcerative colitis and Crohn's disease of the colon. Clin Exp Immunol 1975; 22: 197-209.

22 Rosekrans PCM, Meijer CJLM, Van der Wal AM, Cornelisse CJ, Lindeman J. Immunoglobulin containing cells in inflammatory bowel disease of the colon: a morphometric and immunohistochemical study. Gut 1980; 21: 941-7.

23 Scott BB, Goodall A, Stephenson P, Jenkins D. Rectal mucosal plasma cells in inflammatory bowel disease. Gut 1983; 24: 519-24.

24 Keren DF, Kern SE, Bauer DH. Direct demonstration in intestinal secretions of an IgA memory response to orally 128: 475-9.

25 Scott MG, Nahm MH, Macke K, Nash GS, Bertovich MJ, MacDermott RP. Spontaneous secretion of IgG subclasses by intestinal mononuclear cells: differences between ulcerative colitis, Crohn's disease, and controls. Clin Exp Immunol 1986; 66: 209-15

26 Rüthlein J, Ibe M, Burghardt W, Mössner J, Auer IO Immunoglobulin G (IgG), IgG1, and IgG2 determinations from endoscopic biopsy specimens in control, Crohn's disease and ulcerative colitis subjects. Gut 1992; 33: $507-12$.

27 Chao LP, Steele J, Rodrigues C, Lennard-Jones J, Stanford JL, Spiliadis C, et al. Specificity of antibodies secreted by hybridomas generated from activated $B$ cells in the mesenteric lymph nodes of patients with inflammatory mesenteric lymph nodes of patient

28 Chapman RW, Selby WS, Jewell DP. Controlled trial of intravenous metronidazole as an adjunct to corticosteroids in severe ulcerative colitis. Gut 1986; 27: 1210-2.

29 Malchow H, Ewe K, Brandes JW, Goebell H, Ehms H, Sommer H, et al. European cooperative Crohn's disease study (ECCDS): results of drug treatment. Gastroenterology 1984; 86: 249-66.

30 Morson BC, Dawson IMP, Day DW, Jass JR, Price AB Williams GT. Gastrointestinal pathology. Oxford: Blackwell Scientific, 1990.

31 Harvey RF, Bradshaw JM. A simple index of Crohn's disease activity. Lancet 1980; i: 514 .

32 Andre C, Descos L, Landais P, Fermanian J. Assessment of appropriate laboratory measurements to supplement the appropriate laboratory measurements to supplement

33 Macpherson AJS, Jones-Mortimer MC, Henderson PJF Identification of the AraE protein of Escherichia coli. Identification of the AraE p
Biochem $\mathcal{f}$ 1981; 196: 269-93.

34 Kaback HR. Transport across isolated bacterial cytoplasmic membranes. Biochim Biophys Acta 1972; 265: 367-416.

35 Harlow E, Lane D. Antibodies - laboratory manual. New York: Cold Spring Harbor Laboratory, 1988. 
36 Reinhold R, Fine J. A technique for quantitative measurement of endotoxin in human plasma. Proc Soc Exp Biol Med 1971; 137: 334-47.

37 Choudari CP, O'Mahony S, Brydon G, Mwantembe O, Ferguson A. Gut lavage fluid protein concentrations: objective measures of disease activity in inflammatory objective measures of disease activity in inflammat
bowel disease. Gastroenterology 1993; 104: 1064-71.

38 Breese E, Bragger CP, Corrigan CJ, Walker-Smith JA MacDonald TT. Interleukin-2 and interferon-gamma secreting $T$ cells in normal and diseased human intestinal mucosa. Immunology 1993; 78: 127-131.

39 Mullin GE, Lazenby AJ, Harris ML, Bayless TM, James $\mathrm{SP}$. Increased interleukin-2 messenger RNA in the intestinal mucosal lesions of Crohn's disease but not ulcerative colitis. Gastroenterology 1992; 102: 1620-7.

40 Liblau RS, Singer SM, McDevitt HO. Th1 and Th2 CD4+ $T$ cells in the pathogenesis of organ-specific autoimmune

41 Lombardi G, Sidhu S, Batchelor R, Lechler R. Anergic T cells as suppressor cells in vitro. Science $1994 ; 264: 1587-9$.

42 Bachmann MF, Hoffmann Rohrer U, Kündig TM, Bürki $\mathrm{K}$, Hengarter $\mathrm{H}$, Zinkernagel $\mathrm{H}$. The influence of antigen organisation on B cell responsiveness. Science 1993; 262: 1448-51.
43 Das KM, Erber WF, Rubinstein A. Immunohistochemical changes in morphologically involved and uninvolved colonic mucosa of patients with idiopathic proctitis. $\mathcal{F}$ Clin Invest 1977; 59: 379-85.

44 Engstrom JF, Arvantis C, Sagawa A, Abdou NI. Secretory immunoglobulin deficiency in a family with inflamimmunoglobulin deficiency in a family with inflammatory

45 Halstensen TS, Das KM, Brandtzaeg P. Epithelial deposits of immunoglobulin Gl and activated complement colocalise with the $\mathrm{Mr} 40 \mathrm{kd}$ putative autoantigen in ulcerative colitis. Gut 1993; 34: 650-7.

46 Bjarnason I, Williams P, Smethurst P, Peters TJ, Levi AJ. The effects of NSAID and prostaglandins on the permeability of the human small bowel. Gut 1986; 27: 1292-7.

47 Noone C, Menzies IS, Banatvala JE, Scopes JW. Intestinal permeability and lactose hydrolysis in human rotaviral permeability and lactose hydrolysis in human rotaviral gastroenteritis assessed simulateously by non-invasive dif217-25.

48 MacQueen G, Marshall J, Perdue M, Siegel S, Bienenstock J. Pavlovian conditioning of rat mast cells to secrete rat mast cell protease II. Science 1989; 273: 83-5. 